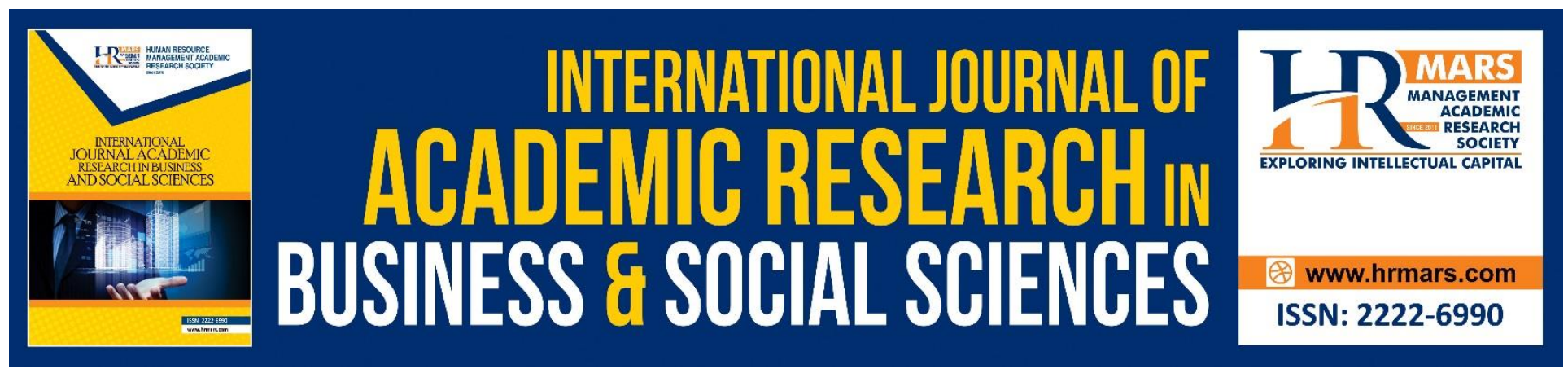

\title{
The Resistance of the Urban Poor in Selangor, Malaysia to Get Out of the Shackles of Poverty
}

Siti Nor Ain Mayan, Radieah Mohd Nor

To Link this Article: http://dx.doi.org/10.6007/IJARBSS/v10-i9/7637

DOI:10.6007/IJARBSS/v10-i9/7637

Received: 07 June 2020, Revised: 12 July 2020, Accepted: 18 August 2020

Published Online: 27 September 2020

In-Text Citation: (Mayan, \& Nor, 2020)

To Cite this Article: Mayan, S. N. A., \& Nor, R. M. (2020). The Resistance of the Urban Poor in Selangor, Malaysia to Get Out of the Shackles of Poverty. International Journal of Academic Research in Business and Social Sciences. 10(9), 602-611.

Copyright: (C) 2020 The Author(s)

Published by Human Resource Management Academic Research Society (www.hrmars.com)

This article is published under the Creative Commons Attribution (CC BY 4.0) license. Anyone may reproduce, distribute, translate and create derivative works of this article (for both commercial and non-commercial purposes), subject to full attribution to the original publication and authors. The full terms of this license may be seen

at: http://creativecommons.org/licences/by/4.0/legalcode

\section{Vol. 10, No. 9, 2020, Pg. 602 - 611}

Full Terms \& Conditions of access and use can be found at http://hrmars.com/index.php/pages/detail/publication-ethics 


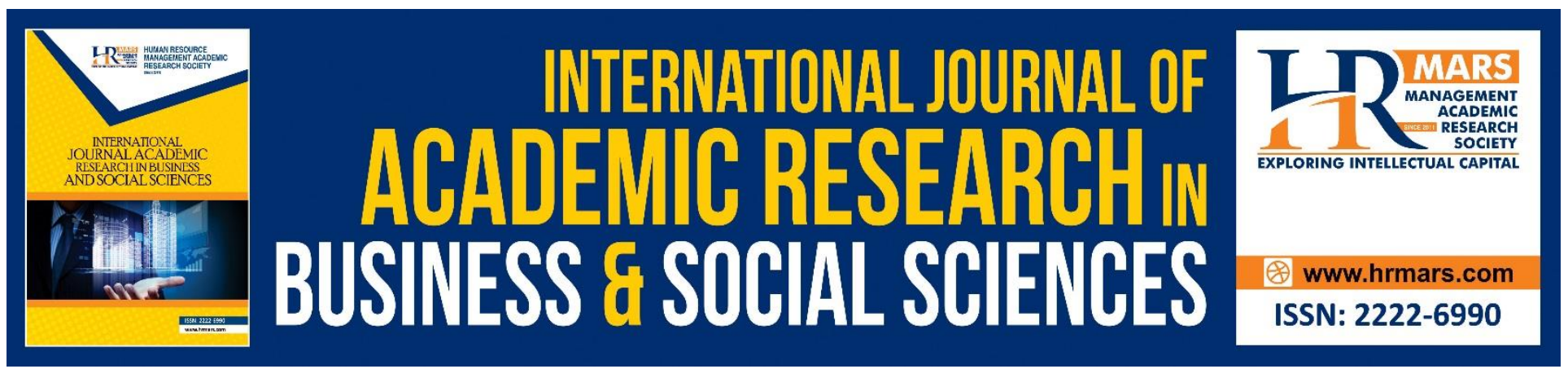

\title{
The Resistance of the Urban Poor in Selangor, Malaysia to Get Out of the Shackles of Poverty
}

\author{
Siti Nor Ain Mayan, Radieah Mohd Nor \\ Centre for Global Sustainability Studies (CGSS), Level 5, Hamzah Sendut Library, \\ Universiti Sains Malaysia, 11800 Pulau Pinang, Malaysia \\ Email: radieah@usm.my
}

\begin{abstract}
The income of households in Malaysia is classified into three groups namely the top 20 percent (T20), middle 40 percent (M40), and bottom 40 percent (B40). The B40 group refers to households earning less than RM 4,850 per month making it the lowest households class in Malaysia. This group is incapable to accommodate the cost of living especially in urban areas as their monthly income is insufficient to make ends meet. This research examines the challenges faced by the B40 group to elevate their income and standard of living to take them out of the poverty group. The methodology of this research employed face-to-face interviews. 20 respondents were chosen randomly from five selected areas in the state of Selangor. These five areas were Bandar Petaling, Petaling, Sungai Buloh, Damansara and Bukit Raja. Based on the content analysis conducted, various challenges have been found namely the problem of single mothers, the lack of skills and education, health problems, cost of living, and individual attitude. To overcome these challenges, a number of suggestions are proposed which are exposure to existing skills programmes, increasing the quality of healthcare, controlling the price of goods, and regular visits to living areas of the B40 group.
\end{abstract}

Keywords: B40 Group, Urban Poor, Cost Of Living, Selangor.

\section{Introduction}

The cost of living in urban areas is definitely higher than in rural areas. City residents are vulnerable to the threat of poverty. According to the United Nations, the population of the world will increase from 3.3 billion people in 2008 to almost 5 billion by 2030. In cities across the globe, hundreds of millions of people suffer from poverty without access to a comfortable shelter, clean water, and proper disposal of waste and excrement (Garland, et.al 2007). According to Siti Syamila Amir Hamzah (2015), the increasing cost of living does not correspond to income earned resulting in the households facing various problems related to poverty. In Malaysia, the B40 group is the bottom group earning less than RM 4,850 (Abdullah, 2018). This group consists of poor and extremely poor households (Abdullah, 2017). The B40 group has to compete with the middle (M40) and upper (T20) classes to obtain a more comfortable living especially in urban areas (EPU, 2014). Therefore, the government has taken the problems related to the B40 group seriously to the point of granting them a special 
INTERNATIONAL JOURNAL OF ACADEMIC RESEARCH IN BUSINESS AND SOCIAL SCIENCES Vol. 10, No. 9, 2020, E-ISSN: 2222-6990 @ 2020 HRMARS

attention in the Eleventh Malaysia Plan (11MP) (EPU, 2015). This research focuses on the B40 group living in the states of Selangor as the urban population present in Selangor is considerably denser compared with other states in Malaysia.

\section{Literature Review}

More than 90 percent of urban growth occurring in developing nations has attracted 70 percent of the people to move to the cities. It was predicted that urban poverty would double in Asia and SubSaharan Africa two decades later (World Bank, 2011). This is due to the fact that more than half of Asian population are urban residents and that the rapid development of cities in Asia, Africa and Latin America has made 600 million people suffer from urban poverty (Poverties, 2011). Urban poverty covers a wide variety of aspects which are the lack of income, weaknesses in providing basic public facilities and services, the lack of job opportunities, and the limitedness in enjoying social facilities (Ab. Ghani, 2007). Besides, access to health facilities and the absence of social security also contribute to urban poverty (World Bank, 2011). As an Asian nation, Malaysia is no exception in being concerned about urban poverty that has taken place. As much as 1.6 million urban residents in Malaysia are categorized into the B40 group. The percentage of B40 group in Malaysian cities is as the following: Figure 1.1 shows the percentage of B40 group households in urban areas by state in Malaysia. The state of Selangor records the highest number of B40 group in urban areas namely $16.6 \%$ with the lowest being in Putrajaya (0.1\%). 


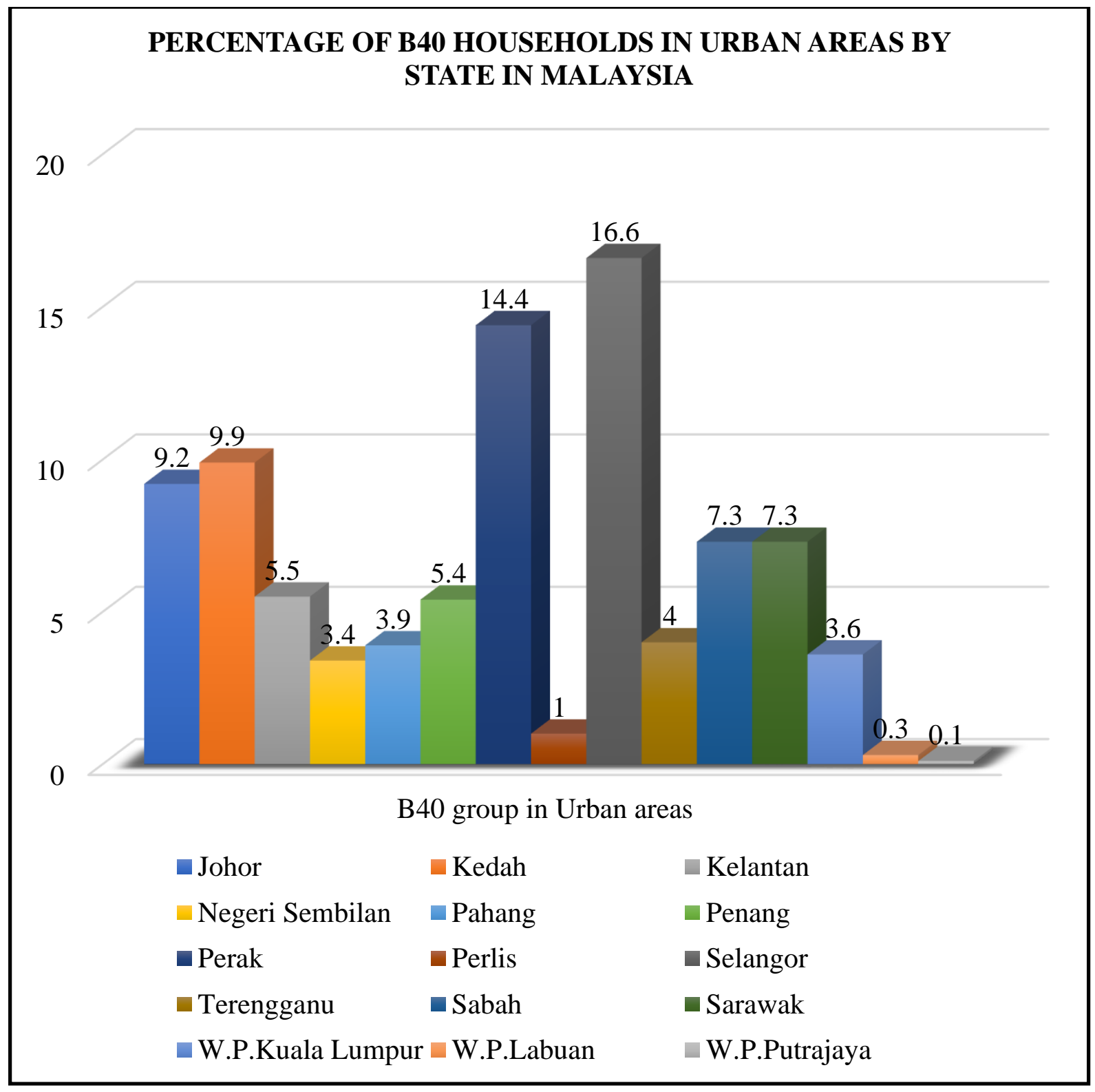

Figure 1.1: Percentage of B40 group households in urban areas by state in Malaysia

Source: EPU (2017)

The B40 group in Selangor is divided according to nine districts. Based on Figure 1.2, the highest number of B40 households in urban areas in the state of Selangor is in the Petaling district which is 5,649 people while the lowest number is in the Kuala Langat district which is 946 people. 


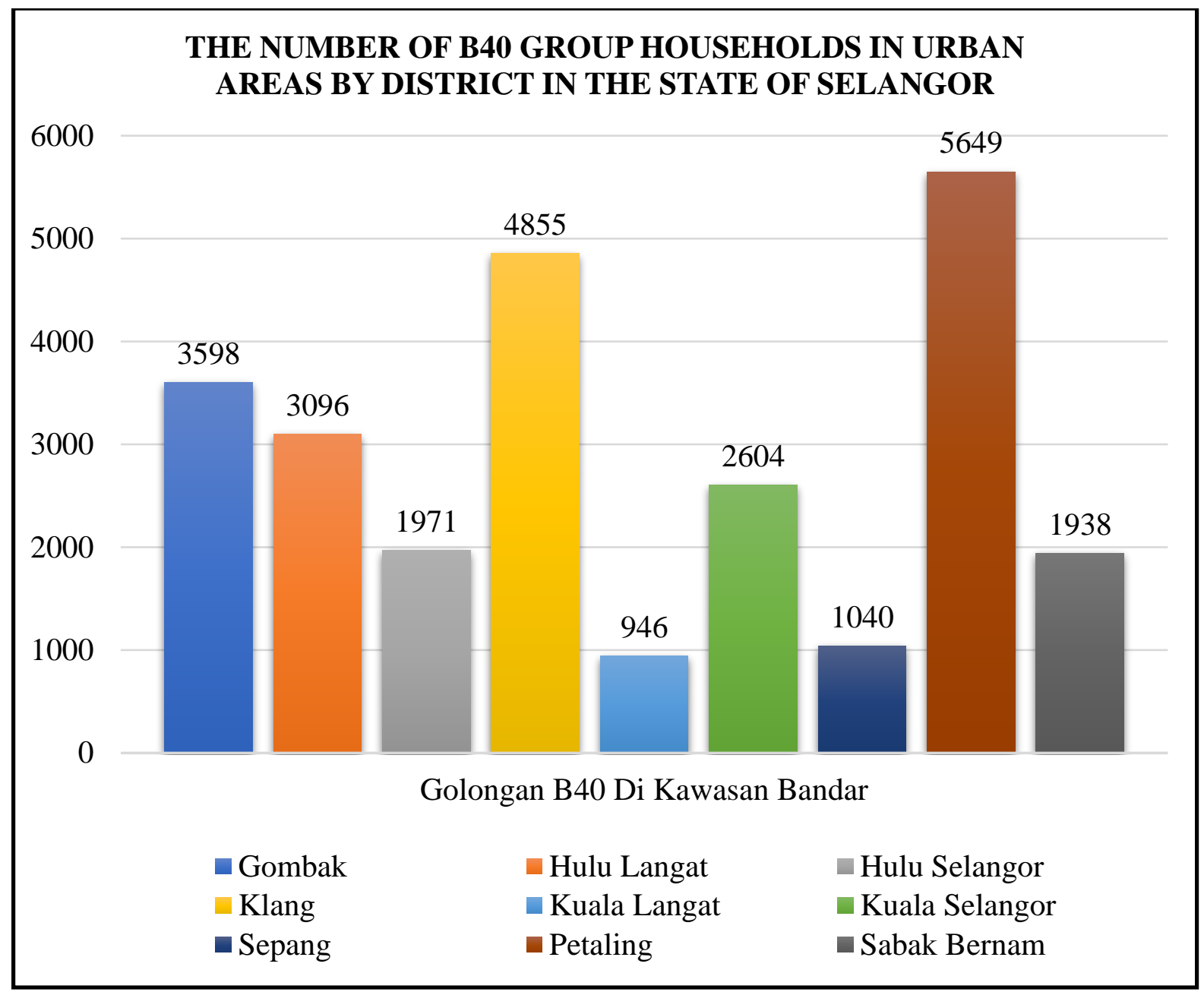

Figure 1.2: The number of B40 group households in urban areas by district in the state of Selangor.

Source: ICU (2018)

The graph shows that the highest number of B40 group is in the Petaling district and this research concentrates on the respondents living there. The Petaling district in Selangor is an area gazetted by the state government of Selangor as an urbanised area as the population has exceeded 100,000 people (EPU, 2013). The number of people in this area is more than 619,925 people (Petaling Jaya City Council, 2018). Despite its rapid urbanisation process, urban poverty issue continues to increase. This is proven by the increasing percentage of asnaf (zakat beneficiaries) by $33.5 \%$ which is 5,155 people in 2013 to 6,885 people in 2014 (Aza Shahnaz Azman et.al, 2016). Other than that, a research has been conducted in the areas of Petaling Jaya and Kuala Lumpur by the United Nations Children's Fund (UNICEF) on poverty and denial of children's rights in the cities. This research found that poverty results in stunted growth in children, lack of nutritious food, inconducive learning space, and lower percentage of preschool registration. Therefore, this research has been conducted to discover the challenges faced by the B40 group specifically those living in urban areas in Selangor.

This paperwork aims to investigate and examine the challenges faced by the B40 group who are mostly still living at poverty level especially the ones living in the urban areas. This is in line with the government's goal to reduce poverty through the Sustainable Development Goals (SDG) signed by 118 countries advancing towards zero poverty by 2025 (UNDP, 2016). It has also been a national 
INTERNATIONAL JOURNAL OF ACADEMIC RESEARCH IN BUSINESS AND SOCIAL SCIENCES Vol. 10, No. 9, 2020, E-ISSN: 2222-6990 @ 2020 HRMARS

vision to become a high-income developed country (The Prime Minister's Department, 2018). Therefore, poverty has to be reduced to achieve these national and international visions.

\section{Methodology}

The methodology of this paperwork employed primary and secondary data. The primary data was obtained based on respondents' information provided by the Implementation Coordination Unit (ICU) of The Prime Minister's Department. ICU is a poverty data bank that also collects the data of B40 group across the country. From this information, semi-formal research questions were established to interview the respondents face-to-face. The respondents were classified based on five locations in the Petaling district in Selangor namely Petaling, Bandar Petaling, Damansara, Bukit Raja and Sungai Buloh. The district of Petaling was chosen as it has the highest number of B40 group in the state of Selangor especially in the urban areas (ICU, 2017). Each location was divided into four respondents randomly. The total number of respondents for this research was 20 people. According to Douglas (1985), Lincoln (1989) and Bailey (2007), a total of 20 respondents is sufficient to meet the saturation point representing the whole research population. The researchers have also interviewed an official from the distribution section of the Economic Planning Unit (EPU), Mr. Fairul Rafieq Abdullah who is responsible in managing the B40 group.

The secondary data was obtained from official government reports, local and foreign online materials, library materials and related academic writings. Then, this data was analysed using content analysis method.

\section{Research Findings and Analysis}

This research has interviewed 20 respondents from the B40 group. Each respondent is the Head of Household $(\mathrm{HOH})$ selected randomly from various social and cultural background. These interviews were conducted to figure out the reality of challenges confronted by the B40 group living in urban areas and the best method to overcome these challenges. The respondents' demographic information list is as the following:

Table 1: Respondents' demography

\begin{tabular}{|l|l|r|}
\hline Gender & Male & 2 \\
& Female & 18 \\
\hline Race & Malay & 17 \\
& Chinese & - \\
& Indian & 2 \\
& Others & 1 \\
\hline Status & Single & - \\
& Married & 12 \\
& Widow & 8 \\
& Widower & - \\
\hline Age & $20-29$ & 1 \\
& $30-39$ & 1 \\
& $40-49$ & 9 \\
& $50-59$ & 4 \\
& $60-69$ & 4 \\
\hline
\end{tabular}


INTERNATIONAL JOURNAL OF ACADEMIC RESEARCH IN BUSINESS AND SOCIAL SCIENCES Vol. 10, No. 9, 2020, E-ISSN: 2222-6990 @ 2020 HRMARS

\begin{tabular}{|c|c|c|}
\hline $\begin{array}{l}\text { Education } \\
\text { Level }\end{array}$ & $\begin{array}{l}\text { Not schooled } \\
\text { UPSR } \\
\text { PMR } \\
\text { SPM } \\
\text { STPM } \\
\text { College/ University } \\
\text { Skills Certificate }\end{array}$ & $\begin{array}{l}1 \\
3 \\
9 \\
5 \\
1 \\
- \\
1\end{array}$ \\
\hline Health Level & $\begin{array}{l}\text { Has a medical } \\
\text { condition } \\
\text { Has no medical } \\
\text { condition }\end{array}$ & 16 \\
\hline Employment & $\begin{array}{l}\text { Unemployed } \\
\text { Daily } \\
\text { Contract } \\
\text { Permanent } \\
\text { Self-employed }\end{array}$ & $\begin{array}{l}6 \\
3 \\
2 \\
4 \\
5\end{array}$ \\
\hline Income & $\begin{array}{c}\text { RM 0 } \\
\text { RM1 - RM499 } \\
\text { RM500 - RM999 } \\
\text { RM1,000 - RM1,499 } \\
\text { RM1,500 - RM1,999 } \\
\text { RM2,000 - RM2,499 } \\
\text { RM2,500 - RM2,999 } \\
\text { RM3,000 }\end{array}$ & $\begin{array}{r}- \\
- \\
12 \\
6 \\
- \\
2 \\
-\end{array}$ \\
\hline
\end{tabular}

Based on the demographic information obtained, five challenges were identified namely the problem of single mothers, the lack of skills and education, health problems, cost of living, and individual attitude.

\section{Single Mothers Problem}

Almost half of the $\mathrm{HOH}$ were single mothers. The number of female respondents interviewed was 10 with 8 of them being single mothers. One of them is a domestic abuse victim who ran from her spouse's house, three were left by their husbands without financial support while four were divorced. Being single mothers is extremely burdensome as they have to accommodate the needs of their children without the help of a spouse. They are vulnerable to poverty especially due to health problems and low education level. Therefore, they struggle to find employment and work with small earnings. On top of that, one $\mathrm{HOH}$ admitted to have earned money by prostituting herself to support the needs of her children. This proves that poverty does not only harm the economic aspect but also disrupt the social one. It is no wonder that poor women are always in the cycle of poverty due to their incapacity to provide comfortable needs for their family.

\section{Lack of Skills and Education}

Based on the demographic information listed, 19 of the $\mathrm{HOH}$ interviewed had received formal education be it from primary school, secondary school or college/university. Only one of the $\mathrm{HOH}$ 
had never been to school. Three of them received formal education at the primary level until UPSR, fifteen received secondary level education with nine until PMR while five SPM, and one owns an STPM certificate. Meanwhile, only one has first level culinary skills certificate (basic). None of the $\mathrm{HOH}$ had the opportunity to further their education to a higher level such as college and university. The lack of skills and education resulted in them having to compete for employment especially in densely populated urban areas. Moreover, according to Nor Aini and Chamhuri (2003), urban sectors is unable to provide a lot of jobs and there is a competition to earn a profitable salary. This is proven by referring to the respondents' demographic information which shows that out of the $20 \mathrm{HOH}$ interviewed, only four are permanently employed as opposed to the other five who are employed on contract or daily basis. On the other hand, five are self-employed while six unemployed due to age, health and lay-off factors. According to the respondents, they also have to compete with foreigners to work in informal sectors such as to be a fisherman, cook, lorry driver, etc. This has resulted in pressure and challenges to this group to increase their income and elevate their standard of living.

\section{Health Problems}

From the interviews with the respondents, only four $\mathrm{HOH}$ were found to have no medical condition, 16 suffer from various medical conditions and three are taking care of a spouse with medical conditions. Examples of medical conditions suffered from are hole in the heart, stroke, thalassemia, asthma, diabetes, high blood pressure, obesity, arthritis and osteoporosis, kidney failure, nerve pain, haemorrhoids, and enlarged heart. Some of the $\mathrm{HOH}$ suffer from critical medical conditions and require intensive treatment. This is harmful to the capacity of the $\mathrm{HOH}$ to increase their income. Other than that, some of them have to look after a spouse suffering from a chronic illness such as kidney failure and stroke. They are forced to pay for burdensome medical expenditure with their low income. Even though some of the $\mathrm{HOH}$ receive assistance for the cost of hospital treatment from the Department of Social Welfare or the Zakat Centre of Selangor, the burden of treatment and care of a patient are done fully by family members at home. For examples, disposable diapers, wheelchair and medications have to be bought on their own from the pharmacy. On top of that, they also struggle to get good healthcare services as they are incapable of going to a hospital to receive treatment due to the lack of money to spend for the travel. They are forced to prioritise basic necessities first such as food and drinks instead of to get medications or treatment at the hospital.

\section{High Cost of Living}

The most significant challenge for the B40 group living in urban areas is the high cost of living. All respondents admitted and agreed that the cost of living is increasing to the point of them being unable to accommodate their daily needs and expenditure. The income earned by the $\mathrm{HOH}$ only ranges between RM 500 and $\mathrm{RM} \mathrm{2,000.} \mathrm{Out} \mathrm{of} \mathrm{all} \mathrm{the} \mathrm{HOH}$, twelve are categorised as extremely poor, two as poor and six as borderline poor households. This low income has caused the $\mathrm{HOH}$ to be incapable of providing sufficient basic necessities to their family members. The $\mathrm{HOH}$ are indeed in need of assistance from government institutions to help them gain the basic needs to continue living in urban areas. Furthermore, the people especially those in the B40 group are the most severely affected by the rising cost of living resulted from the increased price of goods (Rohami Shafiee, 2011). Besides, single mothers also experience the pressure of the rising cost of living as they are breadwinners with low income (Diyana Ishak, Doris Padmini, Nor Aini Idris, 2009). They are unable to accommodate the rise in the cost of daily necessities, let alone the cost of sending their children to 
INTERNATIONAL JOURNAL OF ACADEMIC RESEARCH IN BUSINESS AND SOCIAL SCIENCES Vol. 10, No. 9, 2020, E-ISSN: 2222-6990 @ 2020 HRMARS

school, healthcare, and residence. Generally, the $\mathrm{HOH}$ interviewed do not own a home and have to rent the Hardcore Poor Housing Project (PPRT) flats. They are incapable of renting any other place let alone buying a house.

\section{Individual Attitude}

After examining the interviews conducted on the respondents, the researchers found that the attitude of the $\mathrm{HOH}$ themselves also contribute to their income level. First, the shyness and pessimism of some of those in the B40 group result in them not wanting to apply for an aid and feeling that it is quite difficult to get an aid especially from the government. Second, the lack of competitive spirit contributes to the group being reluctant to start a business to avoid competing with others even when they already have the skills and equipment required. This has resulted in them shifting from business to wage employment. Third, they are too dependent on government aids especially the 1Malaysia People's Aid (BR1M). The people in the B40 group are more interested in a cash aid compared with other forms of aid such as training and business aids. A majority of them are aware of the BR1M assistance more than any other government aid allocated for the B40 group.

\section{Solutions}

There are a number of methods to overcome the problems and challenges confronted by the B40 group. These methods involve the concerned ministries and departments raising awareness about the existing programmes. Advertisements through mass media on free training programmes will provide a wide exposure to the people especially the B40 group. Besides, the government has to elevate the quality of healthcare services and find a way to overcome the problem of the poor being incapable to go to a hospital due to economic factor. For example, the Door2Door Doctor (D2DD) service should be expanded to cover government hospitals as it provides a service to transport patients to receive free medical treatment. To get a treatment, a patient only has to call the D2DD service and a D2DD ambulance would go to the patient's house to bring him/her to a clinic for medical check-up. For the time being, the D2DD project is only carried out by a private individual (Kosmo, 2015).

Next, to reduce the cost of living, the government should be strict at controlling the price of goods and breaking the monopoly of middlemen raking in profits before selling the products to retailers. Moreover, regular visits to residences of the B40 group such as PPRT flats could be conducted by concerned ministry to observe and fathom the problems of the poor at the locations. This can be done, for example, by providing a mobile counter giving out information about aids and programmes implemented by the government for the B40 group. Other than that, the ministry can also obtain direct information regarding problems faced by this group.

\section{Conclusion}

In conclusion, to attain zero poverty aim which has been a main goal of countries around the world especially Malaysia. The challenges faced are the reality of the B40 group in the effort to improve their standard of living. There should be a continuous solution that is both practical and suitable with the situation and the needs of the B40 group so that they could elevate their income level and liberate themselves from the shackles of poverty. 
INTERNATIONAL JOURNAL OF ACADEMIC RESEARCH IN BUSINESS AND SOCIAL SCIENCES Vol. 10, No. 9, 2020, E-ISSN: 2222-6990 @ 2020 HRMARS

\section{Acknowledgement}

The researchers are thankful to the Universiti Sains Malaysia as this paperwork was sponsored by the University Research Grant (RUI) [1001/PCGSS/816308]. The researchers also thank everyone who was involved either directly or indirectly in this research.

\section{References}

Bailey, C. A. (2007). A guide to qualitative field research. Pine Forge Press: USA.

EPU, Economic Planning Unit. (2015). Rancangan Malaysia Ke-11 (2016-2020) Pertumbuhan Berpaksikan Rakyat. Retrieved from http://www.moh.gov.my/index .php/ pages/view/1494. Abdullah, F. R. (2017). EPU, Economic Planning Unit. Economic Planning Unit: Putrajaya. Abdullah, F. R. (2018). EPU, Economic Planning Unit. Economic Planning Unit: Putrajaya.

Garland, A. M., Massoumi, M., \& Ruble, B. A. (2007). Introduction: Global urabn Poverty: Setting the Agenda. Woodrow Wilson International Centre for Scholars: Washington.

ICU, Implementation Coordination Unit. (2008). Info eKasih. https://ekasih.icu.gov .my/Pages /InfoeKasih.aspx.

ICU, Implementation Coordination Unit. (2017). Data maklumat kumpulan B40. Putrajaya. Jabatan Perdana Menteri, (2018) Wawasan. Retrieved from 2020http://www.pmo.gov.my/ dokumenattached/Dasar/22PERSPEKTIF_WAWASAN_2020.pdf

Kosmo online. (2018). Kemiskinan bandar dan kanak-kanak. Retrieved from http://www.kosmo.com.my/ jurnal/kemiskinan-bandar-dan-kanak-kanak-1.629140

Kosmo online. (2015). Perkhidmatan doktor bertauliah di rumah. Retrieved from http://ww1.kosmo.com.my/kosmo/content.asp?y=2015\&dt=1011\&pub=Kosmo\&sec=Renca na_Utama\&pg=ru_01.html

Majlis Bandaraya Petaling. (2018). Latar Belakang. Diakses daripada http://www.mbpj.gov $. \mathrm{my} / \mathrm{ms} / \mathrm{mbpj} /$ profil/latar-belakang

Idris, N. A. H., \& Siwar, C. (ed.) (2003). Kemiskinan Bandar dan Sektor Tidak Formal di Malaysia. UKM Publication: Bangi.

Lebar, O. (2015). Penyelidikan Kualitatif: Pengenalan Kepada Teori dan Metode. Universiti Pendidikan Sultan Idris: Perak.

Poverties. (2011) Urban Poverty: Tackling the Roots Of Future Poverty? Retrieved from, http://www.poverties.org/urbanpoverty.html\#sthash.rFLo9KwD.dpuf

Hamzah, S. S. A. (t.t) Pengaruh Kemiskinan dalam Ekonomi Malaysia. Retrieved from, file://C:/Users/Thunder\%20Match/Downloads/golongan\%20B40/Pengaruh \%20Kemiskinan\%20dalam\%20Ekonomi\%20Malaysia.pdf

United Nation Development Programme. (2016). Sustainable Development Programme (SDGs). Retrieved from http://www.undp.org/content/undp/en/home/sdgoverview/ post-2015development-agenda.html

World Bank. (2011). Urban poverty: An overview. Retrieved from http://web.worldbank .or /WBSITE/EXTERNAL/TOPICS/EXTURBANDEVELOPMENT/EXTURBANPOVERTY/0,,contentMDK :20227679 menuPK:473804 pagePK:148956 piPK:216618 theSitePK:341325,00.html 